\title{
Capital Crimes: John Thelwall, 'Gallucide' and Psychobiography
}

Keywords: Thelwall, jacobin allegory, animal fable, guilt, psychobiography, Lyrical Ballads

It is no longer an outlandishly jacobin critical move to cite Wordsworth and Coleridge as a context for a reading of John Thelwall. For too long a political caricature and mere anecdote in the narrative of Wordsworth's and Coleridge's youthful radicalism, Thelwall is now recognised not only as one of the most impressive thinkers and voices of the 1790s reform movement and as a pioneering speech therapist in his 'second life', but also as a paradigmatic Romantic author whose enfranchising experimentation with a variety of genres forged a new kind of literary-political discourse. The probing collection of essays on this 'radical Romantic and acquitted felon' edited by Steve Poole (2009), the issue of this journal (16, 2; July 2010) devoted to Thelwall, and the founding of The John Thelwall Society on 4 January 2012 at an international gathering in Oxford are only the most recent interventions in a dynamic, burgeoning field.

Critics have been drawn in particular to Thelwall's jacobin allegories, satires and fables of the 1790s, the most politically eventful time of his career. These allegories, whose strategies of indirection mark the pressures of anti-jacobin regulation, have appealed to Romanticists owing to what Michael Scrivener calls their 'characteristically allusive and semantically elusive' methods. As sites of 'print-culture incursion into popular oral culture', Thelwall's fables became 'object[s] of contestation over legally permissible political expression'. ${ }^{1}$

\section{I: 'Gallus ex Machina', 1793-5}

Here, I wish to offer a new context for one of Thelwall's most teasing and politically far-reaching literary fables - 'King Chaunticlere; or, The Fate of Tyranny' (1793), which he revisited ('resurrected' might be a more apposite term, given its subject) in 1795 in the satirical poem, John Gilpin's Ghost; or, The Warning Voice of King Chanticleer: An Historical Ballad. A hitherto overlooked material (rather than exclusively literary) prompt can be seen to lie behind Thelwall's culturally complex farmyard tyrant - namely, the representation of the cock Chanticleer, popularised in England by Chaucer's The Nun's Priest's Tale, on the capital of the first pier of the south aisle in All Saints parish church, Oakham, Rutland. As an imaginative prompt, this architectural embellishment and visual exemplum allows us to see the characteristic permeability of the boundaries between the period's cultures of antiquarianism, literary endeavour, orality and political opposition. In a psychobiographical move, I also suggest that

Romanticism 18.1 (2012): 55-69

DOI: $10.3366 /$ rom.2012.0064

(C) Edinburgh University Press

www.eupjournals.com/rom 
Thelwall's invocation of the gamecock in satires (of various kinds) between 1793 and 1798 should be understood in the context of the relation between the capital, the resonant ideological space in which it is located, and an event of great emotional importance in Thelwall's life. The gamecock became for Thelwall a personal symbol and conflicted talisman. What one might call historicist psychobiography reveals the genetics of a major 1790s jacobin trope.

First, an account of the strange and strutting life of Thelwall's gamecock allegory in the literary and disciplinary spaces of the early 1790s is necessary. In November 1793, Daniel Isaac Eaton, who had already been prosecuted for publishing Tom Paine, cocked a snook at the state's 'repressive apparatus ${ }^{2}$ by publishing in the November 1793 issue of his periodical, Politics for the People, or Hog's Wash, an 'anecdote, related by Citizen Thelwall, at the Capel Court Society'. ${ }^{3}$ Seeking to illustrate the principle that the 'love of life' is a more powerful imperative than the 'love of liberty', the previous speaker at the gathering had drawn a nightmarish portrait of a 'poor kidnapped negro' who, 'on account of some seditious attempt to regain his freedom', had his hands and feet amputated and was 'afterwards put into a large frying pan over the fire'. ${ }^{4}$ When one of his companions, 'more compassionate than the rest', raised a cudgel in order to end his miseries, the slave lifted his 'bleeding stumps' to parry the blow. Thus the previous speaker concluded that the 'love of life' outweighed the 'love of liberty'. Countering what he saw as the speaker's 'cock and bull' reasoning, Thelwall, in a move that married jacobin politics and his interest in scientific materialism, responded with 'King Chaunticlere; or, The Fate of Tyranny'. The fable centres on 'a very fine majestic kind of animal' Thelwall claims he owned in his youth-'a game cock: a haughty, sanguinary tyrant, nursed in blood from his infancy'. Since a guillotine is not to hand,
Thelwall, casting himself in the fable as only a nascent radical, still partly in thrall to the aristocratic splendour of the bird, finally drags the tyrant to the block and beheads him with a 'heavy knife', at which point the scales fall from his eyes and he sees the apparently magnificent bird as what he is: merely 'a common tame scratch-dunghill pullet'. Though now headless, the bird continues its habit of 'spurring, and scuffling about ${ }^{\prime} .{ }^{5}$

The fable cannily serves a number of purposes. It acts as a riposte to the previous speaker by emphasising that the slave victim's actions were merely 'a spontaneous vital action of the nervous system'. ${ }^{6}$ It also deploys autobiography (fabled or not) as a mode of opposition in which the killing of the cock becomes a moment of radical convincement in Thelwall's own life - a bloody version of a methodist conversion that seems to gesture at the fact (as John Barrell notes) that the "love of liberty" can prompt us to escape the influence of [loyalist] habit on our behaviour' and that 'habitual "muscular action" can be changed by "mental action" '. ' Further, it highlights state tyranny (in the bird fable) and imperialist depredation (in the slave story) by invoking the debates and discourses of the revolution controversy. And of course, it persuades, educates and thus emancipates its audience through the ludic substitutions of the animal fable. $^{8}$

The forces of regulation saw in the tale 'an imagining, in the weak sense, of the king's death', ${ }^{\prime}$ and Eaton, as publisher, was indicted for seditious libel. Eaton himself issued the full indictment as a pamphlet, headed by a woodcut of a crowing cock. Following each mention of Thelwall's gamecock, square brackets enclose the prosecution's interpretation of the allegory: 'meaning thereby to denote and represent our said LORD THE KING' (technically called an 'innuendo', as the defending lawyer, John Gurney, explained to the jury during the trial). ${ }^{10}$ This innuendo (from the Latin 'by 
nodding at, pointing to, meaning, intimating') is repeated with such cocksure frequency as to render it absurd and, as Gurney emphasised, allow the prosecution itself to articulate treason by repeatedly enunciating the equation between cock and king. One of the Defence Counsel's most entertaining remarks to the jury in February 1794 was: 'upon the principle of this prosecution... Aesop's Fables, is the most seditious book that ever was published... There is scarcely a fable that will not furnish an indictment ${ }^{\prime}{ }^{11}$ Eaton was acquitted, and immediately changed the sign of his publishing business to 'a cock crowing to rouse some pigs - the swinish multitude - from sleep ${ }^{\prime} ;{ }^{12}$ the London Corresponding Society even struck a medal depicting Thelwall's 'Chaunticlere' ${ }^{13}$

As Michael Scrivener has noted, Thelwall's multi-tasking (and orthographically unstable) gamebird is indebted to 'the figure of chanticleer from folklore', Chaucer's The Nun's Priest's Tale (in which the story of the proud cock 'Chauntecleer', who ultimately outwits the fox, follows the Monk's exempla of the mighty who have fallen), and Caxton's 'Reynard the Fox' ${ }^{14}$ One might also include later adaptations of the fable by Henryson and Dryden; Barrell adds to the list a long 'verse fable' published in the Morning Chronicle in 1793, 'which may also be by Thelwall', in which 'the French nation appears as a gamecock', initially interpellated by the state as a pliant subject, but then roused to a desire for liberty..$^{15}$ The history of 1790s trials clearly shows that Thelwall's bird played an important role in 'test[ing] the limits' of the 'hermeneutical rule ${ }^{\prime 16}$ by which the state interpreted not just libel but treason, too-the charge on which Thelwall himself would soon be brought to the bar.

Thelwall's gamecock ran and ran. Recognising the testing political valence of his fable, he deployed it again very soon after Eaton had been acquitted. This time, the gamecock appeared in an ad hominem satirical ballad narrative that registered Thelwall's own experience of state surveillance and regulation: John Gilpin's Ghost; or, The Warning Voice of King Chanticleer: An Historical Ballad. The autobiographical context summoned in 1793 in 'King Chaunticlere' (Thelwall as bird-fancier-turned-'gallucide') now becomes explicitly politicised. The ballad was published in 1795 after Thelwall's own acquittal. As its title-page emphasises, it was 'written before the late trials' and is dedicated 'to the treason-hunters' of Oakham - the county town of Rutland, with which Thelwall was familiar since it was here that he met his future wife, Susannah ('Susan' or 'Stella') Vellam (not 'Vellum', as the name is usually given ${ }^{17}$ ), an Oakhamite born and bred; they were married there in July 1791. As I hope to show, the architecture of the physical space in which the marriage took place is the gravitational centre of Thelwall's fascination with the gamecock fable. The preface to John Gilpin's Ghost explains that soon after Eaton's acquittal, Thelwall sent 'a small packet of books' to his wife's brother, John ('Jack') Vellam, at Oakham, including a copy of 'King Chaunticlere; or, The Fate of Tyranny' and Eaton's indictment (with the proud gamecock woodcut):

But a conspiracy to intercept my papers had been formed by the great men of Oakham (particularly Mr. John Combes, attorney at law, and agent to Lord Winchelsea; the Rev. $\mathrm{Mr}$. Williams, who afterwards displayed the critical accuracy of his optics by swearing to my $T^{\prime} s$ and $h^{\prime} s$, in consequence of having seen me sign my name to the register of my marriage, and Mr. Apothecary Berry, who swore he would sell his whole estate but he would hang me!) and these books, by some accident or other... fell into Combes's hands. The Oakhamites were in consequence all in a flame. Nightly meetings were held at 'the Crown', which is the principal inn at Oakham; the house of my brother-in-law was broke open, and rifled of papers, books, 
letters, \&c. and lawyer Combes was posted to London to acquaint the GREAT MAN in DOWNING-STREET with the wonderful discovery. ${ }^{18}$

Thelwall referred to the 'infamous \& illegal transaction' of the Oakham loyalists in a spirited letter of 10 March 1794 to his brother-in-law, which confirms that the latter's papers had also been seized. ${ }^{19}$ The actions of the local posse - the 'Loyal Association of Oakhamites', as Thelwall calls them in marginalia in the British Library copy, in a parodic echo of John Reeves's Association for Preserving Liberty and Property against Republicans and Levellers - gave rise to the ballad, John Gilpin's Ghost..$^{20}$ The poem 'escaped the general pillage' when Thelwall was arrested in 1794 since it was 'in the pocket of an old waistcoat': a dark radical space, close to the 'treasonous' body, from which it issued into the public domain in 1795 to be published 'at the Sign of the Pop-Gun' - a sly reference on the title-page to the alleged 1794 plot to assassinate King George III in a theatre. ${ }^{21}$ As advertised by Thelwall's title, the poem's supernatural 'machinery' derives from William Cowper's comic ballad, 'The Diverting History of John Gilpin', which concerns John Gilpin's epic-absurd ride on the anniversary of his wedding. As we shall see, matrimony is a significant element around which the personal resonance of Thelwall's allegory coheres.

Thelwall has Gilpin's spectre disturb the slumbers of Oakham's lawyer Combes, whom he identifies as his son from an adulterous liaison (Thelwall jotted down some rather scurrilous marginalia on this point). ${ }^{22}$ The ghost informs Combes that a 'dreadful lot is on the road / OF TREASON and SEDITION' Thelwall's packet of books, bound for Oakham - and transports Combes to Biggleswade, where the lawyer finds the jacobin packet under 'an old dame's petticoats'. It is from this private female space that Combes secures the dangerous parcel of texts (loyalist surveillance represented as sexual outrage); he then races back to the Crown inn at Oakham. The ballad is shot through with a virulent anti-clericalism: the gamebird-hunting 'Rev. Mr. Williams' is seen 'trembling for his tithes' in the company of 'his buxom maid'; Scrivener notes that as a fowler, the clergyman would have been 'protected, of course, by the brutal Game Laws' ${ }^{23}$ There with him are 'Orme' and 'Haley', identified by Thelwall in the British Library copy as 'Two other loyal Revends [sic] of Oakham: the latter Master of the foundation school'. Together, the priests form 'a goodly trinity', 'Three persons, one in mind!'. The Church is represented as 'in wedlock join' $\mathrm{d}^{\prime}$ with the State-matrimony configured as an illicit, tyrannous union of secular power and spiritual presumption. When Combes arrives with Thelwall's packet, out springs Thelwall's old gamecock, now thoroughly gothicised:

When lo! a feather'd hero bounc'd,

A mangled sight, to view,

And stretch'd his headless neck and cried

'Cock-cock-a-doodle-doo!'

And still he spurn'd and flapp'd his wings, And shook his spurs of steel,

While trembling joints and haggard looks, The council's fears reveal.

For thus prophetic flow'd the strain That pierc'd each wond'ring ear, While priests o'er tythe-pigs, fees and dues, Bequeath'd the parting tear.

$$
\cdots
$$

'My crowing speaks the envious light

That soon must clear the sky;

For kingcraft's, priestcraft's night is past, And Reason's dawn is nigh.

In me behold the fate to which All tyranny must bow, And those who've long oppress'd the poor Shall be as I am now.' 
As Scrivener remarks, referring to what he smartly calls Thelwall's 'gallus ex machina': the Gilpin satire emphatically reinforces the regicidal meanings of the gamecock's decapitation' ${ }^{24}$ Here, the cock is a radical, monitory avian epitaph, resurrected from folk and literary tradition (spiced with a touch of Banquo) and from Thelwall's own political past. The cock-as-revenant aptly figures the radical irrepressibility of a spectral, uncanny work written before the Treason Trials (at which Thelwall faced the death penalty, of course) and which only narrowly escaped confiscation by the state.

I suggest that Thelwall's figure of the admonitory cock, together with the satirical context in which it crows its radical warning, may well be partly indebted to a letter that appeared in The Gentleman's Magazine in May 1785 detailing the role of an officer of the royal household called 'the king's cock-crower'. It was the duty of this official 'to crow the hour, instead of crying it'; practised throughout the night during Lent, the aim of such ventriloquism was 'undoubtedly to remind waking sinners of the august effect the third crowing of the cock had on the guilty apostle St Peter' ${ }^{25}$ The correspondent remarks that the post of 'mimic cock' was active 'till within the present century', and tells how the future George II, not conversant with the custom of the English court, took exception to being crowed at on sitting down to supper, interpreting it as an insult rather than court etiquette. Though acknowledging that the position of king's cockerel was 'discontinued from that time' ('that time' can be dated between 1714 and 1727), and that it is 'no more performed than our sovereigns wash the feet of the poor on Maunday Thursday in person', the writer implies that the post may have escaped the 'late bill for the reformation, as it was called, of the Royal Houshold [sic]' and might still, technically, be on the books.

The letter in The Gentleman's Magazine would have offered Thelwall a striking model of cock-crow as admonishment within the 'precincts of the court' and 'purlieus of the palace'. Moreover, he would have relished the political reflex of the queer religious custom. The Thelwall who in John Gilpin's Ghost has his headless cockerel crow the end of 'kingcraft's, priestcraft's night' is himself 'king's cock-crower' for the 1790s. Moreover, the inherent absurdity of the royal office as described in The Gentleman's Magazine would have been recalled through the lens of Paine's attack on titles in Part 1 of The Rights of Man, in which aristocratic 'nick-name[s]' give rise to 'a sort of foppery in the human character which degrades it', a species of 'punyism' that incarcerates the titled subject 'within the Bastille of a word'. ${ }^{26}$ The letter might also have proved influential in its ludic tone, ironic indirection and radical inflection. At first, the correspondent seems loyally to lament the passing of royal ceremony: 'I do know that in most seasons, wherein a pretended rage for reformation prevails, many customs, whose origin did in reality aim at reforming our manners and lives, are confounded with abuses, and levelled indiscriminately'. Indeed, he announces that a number of reasons 'concur for restoring the office' of royal cock-crower'. But then the irony is deployed more obviously as a mode of political challenge:

As courtiers too do not at present retire to rest till morning, the cock-crower would have much more chance of striking terror into their guilty minds, as happened to St Peter, than by giving his warning to men fast asleep... How awfully would it strike a noble lady, passing through the streets with a row of footmen and torches before her chair, to hear a chanticleer of sonorous lungs crow, 'past four o'clock, and a cloudy morning!' Peter wept; her ladyship might drop a tear. ${ }^{27}$

In addition, since 'the national concerns .... are often agitated in the senate past midnight', the 
restoration of the office of royal chanticleer would provide homebound Members of Parliament (who had, 'like St Peter, been denying their master'), with 'devout mementos of their mortality'; returning from the debating chamber, they would meet 'in the broad-way at Whitehall... a body of cock-crowers iterating the past hour'. Significantly, the correspondent introduces the monitory bird into the (nocturnal) political space of the metropolis - Thelwall's sphere of operation as a radical, satirical 'cock-crower', trumpeting the new radical hour in the ear of reactionary loyalism.

\section{II: The Oakham Capital: Marriage, Church, State}

But there is more at stake here than a new jacobin recension of a European folk and literary tale, significant and dangerously effective as Thelwall's reworking of those materials is. The local and personal contexts of the allegory deserve further scrutiny. For Thelwall, the gamecock carries precise, if tangled, spousal meanings. As we have seen, the Chanticleer fable in Thelwall's hands constantly draws into its wider orbit autobiography, the trope of matrimony (an important element of Chaucer's version, of course, in which Dame Pertelote is a significant presence), and Thelwall's characteristically avant-la-lettre, proto-post-Marxist view of the Church as an ideological state apparatus.

In his pioneering 'politico-sentimental' topographical poem-novel, The Peripatetic (1793), Thelwall charts his journey to Oakham in July 1791 to marry Susannah Vellam - 'a farmer's daughter whom he had met on a vacation in 1788', as Judith Thompson reminds $\mathrm{us}^{28}$ - in an epithalamium-cum-travel poem, 'Epistle to Mercutio': 'Here (Iö Hymen!) Love triumphant dwells / With jest and glee, and sound of merry bells ... / And now no more by angry Fate delay'd, / Eager I fly to clasp the blooming maid' ${ }^{29}$ 'Here' is Oakham, 'on [the river] Catmos' cheerful plains', specifically All Saints, the large and impressive parish church. As well as a generic 'tool' in Thelwall's poetry of post-revolutionary sensibility and disenchantment, Susannah was constructed during the trials and tribulations of the 1790s as Thelwall's lodestar ('Stella') - a touchstone of domestic and ideological support and a true jacobin matron. As Thelwall's second wife and biographer records, Susannah became the subject (or rather the displaced object) of the growing rift in the early-to-mid 1790s between the ever-more-outspoken Thelwall and an increasingly 'cautious' John Horne Tooke (the son of a poulterer), whose protégé Thelwall had been:

It will be remembered that [Horne Tooke] one day said, 'I have no son, citizen, why should not you be my son?' and that the affections of [Thelwall] being pre-engaged, he did not understand the wish conveyed by the observation. After his marriage,

however, upon a certain occasion, speaking of his domestic happiness; 'Ah?' said Horne Tooke, drily, 'you were a foolish man, after all you might have done better!' Upon which Thelwall indignantly, and warmly replied, 'It is impossible, Mr. Tooke; it is impossible I could have done better!' - 'I thank you citizen,' returned Tooke, with much heat, 'I thank you!'30

Might Susannah Thelwall have been not only the subject of Horne Tooke's social snobbery, or the convenient butt of his envy of Thelwall's increasing celebrity (one should not underestimate the psychological guilt bound up with Horne Tooke's 'retirement' to Wimbledon), but also the object of his emotional jealousy? Whatever the dynamics of the relationship, it is clear that Thelwall saw 'Stella' as a citizen-partner and fellow victim of state-sponsored violence. 


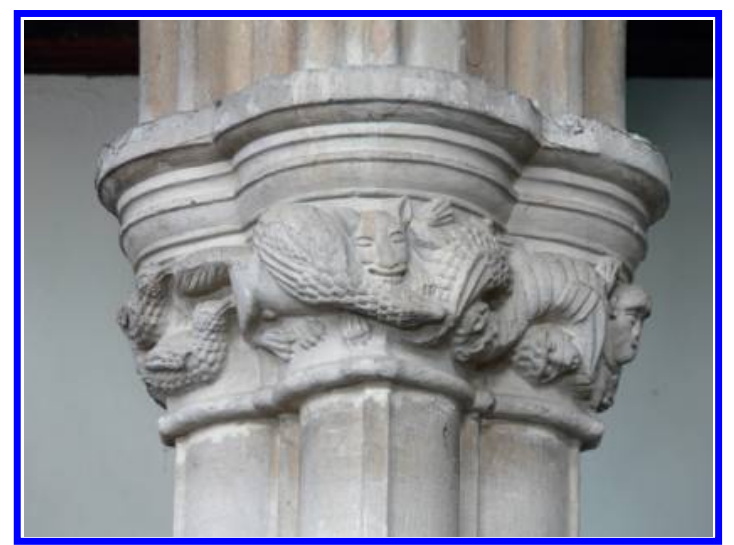

Figure 1. Fourteenth-century capital, south aisle of All Saints Church, Oakham: Thelwall's vulpine talisman.

In the preface to John Gilpin's Ghost, Thelwall mentions the fact that the Revd Richard Williams could testify to his handwriting since he had seen him sign the register of his marriage - an act that is cast in Thelwall's preface as political surveillance. As confirmed by the parish registers, it was indeed Richard Williams, incumbent vicar of All Saints, Oakham, who officiated at the ceremony on 27 July 1791 (Thelwall's birthday, recorded in his poem 'Lines, Written at Bridgewater' as the 'Day of my double birth'). ${ }^{31}$ (Williams was a direct descendant of Sir Isaac Newton; his daughter, Mary, married the celebrated mathematician and nautical astronomer James Inman.) Thus the loyalist priest at the centre of Thelwall's resurrected gamecock satire of 1795 is the very person who sealed the union - in a Christian service, and in a building belonging to the Established Church - of Thelwall and Susannah Vellam.

And here we come to the material talisman mentioned above. The marriage was sealed under a carved fourteenth-century capital on the south aisle of All Saints church, depicting a fox with a bird in its mouth; the fox is chased by two other birds, one of which has the fox's brush in its beak while the other pecks at the fox's hindparts; the other side of the capital displays a woman's head; she holds a distaff and points at the fox; also present is a tethered ape (see Figure 1). ${ }^{32}$ As Kenneth Varty emphasises, although a 'local explanation' is that the fox represents the Abbot of Westminster absconding with a goose (symbolising the great Tithes'), for 'the historian of literature the story behind these sculptures is rather different':

The woman who pursues the fox with a distaff is well known as Dame Malkin to readers of Chaucer's Nun's Priest's Tale, and anybody who has studied the medieval iconography of this tale knows that, in most cases, sculptors substitute a goose or a duck for the cock who is the fox's victim in Chaucer's story. ${ }^{33}$

The Oakham capital dates from the early fourteenth century; the carving therefore belongs to the 'pre-Chaucerian' strand of the Reynard and Chanticleer fable that partly inspired The Nun's Priest's Tale.

As The Peripatetic clearly demonstrates, Thelwall's radical antiquarianism was sharply sensitised not only to the symbols and allegories of medieval architecture, but also to the political exempla that time-ravaged gothic buildings (now put to new democratic use) furnished for contemporary radical narratives dwelling on the ironies of architectural legacies. ${ }^{34}$ Visiting Rochester, Thelwall offers a 
detailed analysis of the 'remains of ancient sculpture' in the cathedral, noting 'the fantastic diversity of pillars and arches in the nave', even detailing the geological makeup of the stone used for the piers: 'It is of a grey colour, with a cast of green, thick set with shells, chiefly turbinated. - Several of these shells are filled with a white spar'. ${ }^{35}$ A master of jacobin ekphrasis, ${ }^{36}$ Thelwall developed what Judith Thompson calls 'a system of "representative aesthetics" - a modification of existing standards of taste and judgement in art, literature, and landscape to take account of the experiences, perspectives, and environments of the excluded majority of the British population'.$^{37}$ Just as a palace, fallen into ruin, could become a democratic barn, so the Chanticleer fable-in both folk-local and literary incarnations - was revivified and further democratised in the 1790s by Thelwall's narratives, centring on Oakham and his own biography.

What, then, was the precise resonance for Thelwall post-1792, say, of that capital in All Saints, under which he was married? I suggest it shared something of the character of one of De Quincey's 'involutes' - 'perplexed combinations of concrete objects' that have gathered to themselves 'compound experiences incapable of being disentangled' ${ }^{38}$ The carving on the capital became a knotty accumulation of political ideologies and aspects of the self that Thelwall's radical Chanticleer narratives sought both to exorcise and to cultivate. With Thelwall, psychobiographical methods yield suggestive insights. The anecdote published by Eaton in 1793, 'King Chaunticlere; or, The Fate of Tyranny', served as a piece of radical life-writing in that it dramatised the moment of its speaker's/author's radicalisation; hitherto indoctrinated as a loyal subject, Thelwall broke the mechanical 'habit' of unquestioning subservience and dragged the tyrannous cockerel to the block, on which Thelwall's own reactionary prejudices were also dispatched. In other words, the fable bespeaks salutary self-murder, which compounds what Scrivener calls the defining 'instability of jacobin allegory' and adds to the hermeneutic difficulties of a government that 'lacked reliable techniques whereby it could with any accuracy translate the intelligibility of a popular oral-culture event into something that was amenable to the interpretive strategies of a judicial prosecution'.$^{39}$ The Oakham bird was a means by which Thelwall imagined not only the king's death, but also his own. Slung over the back of the fox on the Oakham capital, the Chanticleer that had presided over his marriage came to be associated in Thelwall's mind with the reactionary ideology of the very space in which it was located - an edifice of the Established Church - and with his own implied insertion in that system. The very marriage the carved capital had, so to speak, upheld was also part of that network of political regulation and control. In The Peripatetic, Thelwall would offer withering remarks on church services and on the monopoly claimed by the Established Church on 'the grace of inspiration'.$^{40}$ When, as an elocutionary theorist and speech therapist, Thelwall offered a taxonomy of vocal 'monotony' in 1806, three of his categories were pointedly taken from priestly enunciation: 'The Parish Clerk' style, 'The Clerical Drawl', and 'The Cathedral Chaunt'. ${ }^{41}$ One wonders how many of those styles were exemplified by the Revd Richard Williams during the marriage ceremony in July 1791. Against clerical affectations of voice, the very name 'Chanticleer', of course, signifies clarity of song and speech: a radical and post-radical model for Thelwall. Moreover, I suggest that Thelwall would probably have known, through Susannah and her family, of the 'local' interpretation of the Oakham capital as an image of the depredation of the 'great Tithes'. The fable's Chaucerian heritage also encodes a priestly element in that it is of course a priest who tells the story of 'Chauntecleer' in The 
Canterbury Tales. Chaucer gives us his name: most stimulatingly, it is John. ${ }^{42}$

Accruing, then, around the Oakham capital was a complex of contending values and ideologies. I suggest that in a psychologically complex and painful move, John Thelwall had to purge the Chanticleer of All Saints of its pre-radical, orthodox associations; at the same time, he had mentally to free his marriage (sneered at even by a fellow radical) from the constitutive spiritual sanction of a Church in whose beliefs and priestly forms and fables he no longer believed. This he did, I argue, by killing his gamebird in the 1793 allegory and then bringing him home to Susannah's Oakham in 1795 in John Gilpin's Ghost; or, The Warning Voice of King Chanticleer, so that the mangled spectre of the cockerel, who has now been 'educated out of his earlier monarchical prejudices', ${ }^{43}$ can issue a 'warning voice' at the very heart of this loyalist bastion. The cock has become a jacobin cockade - a badge, an ensign. I also suggest that the Oakham capital gave Thelwall his 1790s vulpine identity: looking back on his wedding, Thelwall saw himself as both the gamecock that needed (in the language of the church) to die to his past loyalist life, and the fox who was the agent of that radical rebirth. It was E. P. Thompson who famously christened Thelwall 'the jacobin fox'; Thelwall himself, however, was attuned to the foxy cunning of his craft when he wrote to Stella on 18 July 1797 from 'All fox den' - the syllabic disaggregation giving the place a new radical etymology and fellowship (which subsequent events did not, of course, realise). ${ }^{44}$ The Oakham capital-Thelwall's own complex blazon - bears out Mark Philp's insight that

It seems plausible to read stories, such as Thelwall's 'King Chaunticlere', as part of a process of self-definition, involving experimentation with commitments, identities or political positions... The identities experimented with ... are frequently oppositional and confrontational. ${ }^{45}$

Scrivener rightly remarks that 'the inventive, witty and exuberant satire Thelwall produced in 1793-95 is a result of fused polite and popular literary structures under the extraordinary conditions of sharp political conflict'. ${ }^{46}$ 'Extraordinary conditions' of self-revision, reinvention and spousal love are also in play.

\section{III: Fin-De-siècle Chanticleers}

A truly democratic public subscription coordinated by Judith Thompson, worthy of the generous support networks of the 1790s, recently secured for The Wordsworth Trust's library at The Jerwood Centre, Grasmere, a letter of 24 May 1798 from Thelwall to Thomas Hardy, long presumed lost. Thelwall writes from Llyswen, Breconshire, where the forces of reaction had succeeded in driving him into (ambiguous) 'retirement'. As Thelwall had explained a fortnight earlier in a letter to the 'Bard of Liberty', Edward Williams (Iolo Morganwg), his local poste restante was, aptly, the ' 3 Cocks in the Road to Hay' ${ }^{\prime 47}$ - the coaching inn, two-and-a-half miles from Llyswen, whose sign displayed the coat of arms of the Williams family of Gwernyfed (see Figure 2), ${ }^{48}$ supposedly inherited from the thirteenth-century Welsh nobleman, Einion ap Rhys (nicknamed 'Sais' - 'The Englishman'). I suggest that the armorial blazon, hanging outside a building Thelwall knew intimately, would have appealed to him as iconographic autobiography, a kind of dissident heraldry. 'Argent, a chevron between three cocks Gules' (on a silver shield a red chevron between three red cocks). Marking the charged site of his contact with his (fragmenting) radical networks, the Three Cocks blazon boldly represented the radical reclamation and inflection of the gamecock as cultural and 


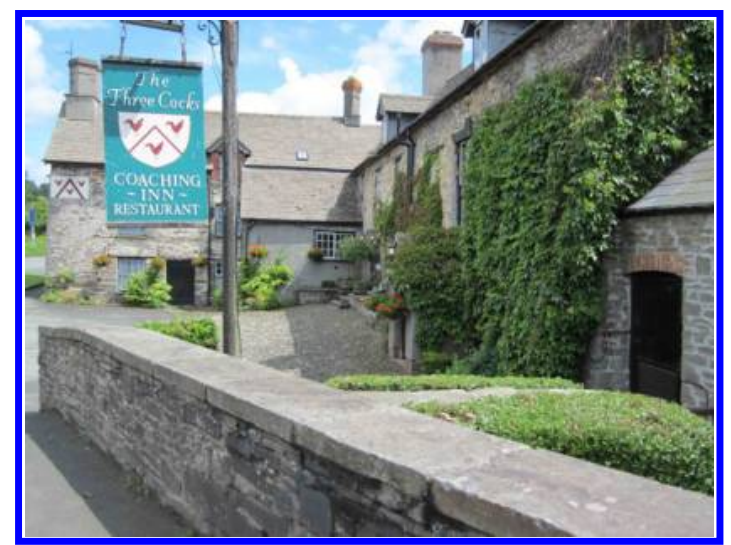

Figure 2. The Three Cocks Coaching Inn, Three Cocks, Breconshire, its sign a painful mnemonic for Thelwall.

political signifier, and the continuing relevance of the gallus figure as the symbol par excellence of Thelwall's radical 'crowing'. Here on a wooden board was Thelwall's 1790s career in the form of a triumvirate of gamecocks - the sculptured Oakham cock, and the two birds of 'King Chaunticlere' and John Gilpin's Ghost. But the shield bore painful and ironic personal meanings, too. It would have served as a visual involute, a mnemonic, of the 'literary \& political triumvirate' comprising Wordsworth, Coleridge and himself that Thelwall had dared to imagine in that letter of 18 July 1797 to Susannah from 'All fox den'. The spatial location of the three cocks on the inn sign is suggestive in this regard: one gamecock is enclosed-incarcerated - beneath the chevron's apex, while there is space for contact between the other two. Thus for Thelwall, this involute was also a memento that raised the still troubling issue of the foxy self-interest that made Coleridge trade 'Thelwall's residence in the neighbourhood for the company of Wordsworth and Dorothy'. ${ }^{49}$

' $[\mathrm{H}]$ abitually unreliable and incipiently apostate' is how Judith Thompson recently described the Coleridge who 'hastened' Thelwall's way to Llyswen..$^{50}$ I suggest that during Thelwall's first spring in Wales, that fickleness (and attendant guilt) cohered around the gilded figure of the gamecock in one of the poems in Lyrical Ballads. A matter of weeks before Thelwall wrote to Hardy in May 1798, Wordsworth composed 'Anecdote for Fathers', in which the young boy, pressured by the adult into choosing between 'sweet Liswyn farm' and Kilve 'by the green sea', chooses the latter on account of the fact that, unlike the farm at Llyswen, it has no weather-cock (a descendant of which still surmounts St Gwendoline's church, visible from Thelwall's property):

His head he raised-there was in sight, It caught his eye, he saw it plain Upon the house-top, glittering bright, A broad and gilded vane.

Then did the boy his tongue unlock, And thus to me he made reply;

'At Kilve there was no weather-cock, And that's the reason why'.

Young Edward's selection of the weathercock as the 'reason' for his preferring West Country Kilve is, on the level of the poem's manifest content, meant to be understood as the arbitrary, enforced act of a child coerced into the 'art of lying' by an insistent, rationalist adult. However, a reading that takes account of the fact that the gallus is Thelwall's 1790s distinctive talisman will be attuned to the 
poem's own 'art of lying' - the way it has itself been pressured into acts of surface fabling. Although our interpretations differ, I agree with David Simpson that the choice of the weathercock 'might have been as precisely motivated for the poet behind the text as it is apparently unmotivated for the child in that text ${ }^{\prime} .^{51}$ I contend that in 'Anecdote for Fathers', Wordsworth, three months before he visited Thelwall in Wales, located the weathercock at Llyswen as the emblem of a radical buffeted by tempestuous political weather. Further, in being rejected in favour of Kilve, this troubling, overdetermined object at Llyswen also registers an anxiety on Wordsworth's part concerning personal and political inconstancy - the weathercock values of the decade's apostatic close. In a taxonomy of the 'professed Friends of Liberty' in his Bristol lectures of 1795 , Coleridge had classed the first type as follows:

Their sensibilities unbraced by the co-operation of fixed principles, they offer no sacrifices to the divinity of active Virtue. Their political Opinions depend with weather-cock uncertainty on the winds of Rumour, that blow from France. On the report of French Victories they blaze into Republicanism, at a tale of French Excesses they darken into Aristocrats... ${ }^{52}$

By the end of the decade, the image of the erratic gallus had become self-incriminating, an unnerving symbol of Coleridge's own unfixed principles. That Coleridgean idea,

'Weather-cock uncertainty', stands in a teasing relation to the 'steady weathercock', 'steeped in silentness' by moonlight at the end of 'The Ancient Mariner'. The latter marks a brief parenthesis of meteorological and spiritual calm before the ship goes down 'like lead'. That it is steady here is also an index of Coleridge's nervous awareness that by now, he is himself open to the very charge of inconstancy he had levelled against the 'professed Friends of
Liberty' in 1795. In 'Anecdote for Fathers', Wordsworth, in a Thelwallian move, summons the steady-uncertain weather-cock as an admonishing presence-a new Chanticleer 'Upon the house-top', 'glittering bright', like the hypnotic, reproving eye of the Ancient Mariner. For Wordsworth, the 'broad and gilded vane' speaks of both gilt and (his and Coleridge's) guilt, and of vainness in two distinct senses: the political defeat of the radical cause, now gone to ground in the figure of Thelwall, and the opportunistic vanity of political default. Wordsworth's response to Thelwallian emblazonry allows us to recognise Lyrical Ballads as a collection in which Wordsworth and Coleridge, like the Ancient Mariner, are doomed to repeat narratives of their own guiltiness. Their fin-de-siècle volume is a collection of 'seditious allegories' turned parables of apostasy, an ideological arena one might legitimately call a cockpit.

Thelwall's recently recovered letter of May 1798 to Hardy articulates a desire to consign political discussion and intervention to the past: 'Peaceful shades of Llyswen shelter me beneath your luxuriant foliages, lull me to forgetfulness ye murmuring waters of the Wye. Let me be poet [,] farmer \& fisherman - but no more politics - no more politics in this bad world ${ }^{\prime} .^{53}$ However, this secular prayer is rendered ironic by mordant comments on the metropolitan political scene. In this respect, the letter points forward to the similarly unstable, rhetorically complex performance of the 'Prefatory Memoir' accompanying Thelwall's Poems, Chiefly Written in Retirement (1801), which served as both an autobiographical apologia and an advertisement for his return to public life. ${ }^{54}$ Significantly, Thelwall is once again moved to resurrect his gamecock at the end of the letter.

The series of psychological prompts that culminate in this last fabling of the Thelwallian gamecock in the 1790s maps the political and personal contexts that had in the first half of the decade motivated Thelwall's treatment of 
the unsettling Chanticleer tale. First, Susannah figures prominently in the letter: 'Stella talks also of enclosing in the parcel by which this [letter] comes to London one of her old Shoes - if she does so be kind enough to get her a pair of Shoes made fit for a farmer's wife's bettermost wear' (as a shoemaker, Hardy was of course the right person to ask). Next, Thelwall takes an explicitly political turn as he wishes Hardy's business continued success in spite of 'Taxes \& Taxmakers', 'the unprincipled wickedness of a plundering \& murdrous [sic] faction of Journeymen Aristocrats or Boroughmongers', and the machinations of the 'ministerial $\mathrm{crew}^{\prime}$ who continue their animosity towards 'the class congregate of acquitted fellons [sic]'. Warming to his theme, he characterises himself as 'little better than a prisoner upon parole' at Llyswen, a planned visit to the Glamorgan coast having been cancelled 'lest it should be made a pretence for seizing us ... under a charge of negociating [sic] a French Invasion'. This exercise in exilic biography rehearses the circumstances and identities of his most dangerous radical years. Further references to the French Directory and Pitt ensue. Then, significantly, satire - the Thelwallian vehicle of the Chanticleer fable-enters the frame in the guise of a critical notice of William Gifford's animated Tory lampoons, followed by the news that the local 'reverend \& zealous minister of the Gospel of Peace' had announced 'a meeting to be held on Wednesday for raising a corps of Llyswen Fencibles', a 'warlike' gathering that was in the event adjourned - either, Thelwall guesses, because 'they found that nobody would attend', or because 'they were afraid they should give me an opportunity of spouting democracy'. All the psychological catalysts are now in place: Susannah Thelwall; aristocrats and the loyalist upper middle classes in league with a repressive government; surveillance; the threat of incarceration; satire as a political tool; and even an antagonistic priest (who, according to the
'Prefatory Memoir' to the 1801 volume would soon stir up hostility towards Thelwall 'by the most pointed and inflammatory allusions from the pulpit $\left.{ }^{55}\right)$.

Tellingly, it is precisely at this moment that the gamecock makes its appearance in the letter-though in a significantly reconfigured fin-de-siècle form:

By the way I have baptised my game Cock Thomas Hardy - being determined for prudential reasons to have no more King Chaunticleres - All my Hens also, have their appropriate names[:] two favorite young hens we have named Mary \& Sophia Goddard, \& their mother Mrs Goddard. Three white sisters we have named Sara, Ester [sic], \& Rose; \& you may inform a certain Gossip who I suppose sometimes entertains you still with a little Democratical scandal that we have one hen excessively impudent but very pretty whom we have named Dame Hazlit -

Farewell remember me to all Citizens

Yours J. T. ${ }^{56}$

Although Thelwall's tyrannous, then gothic, gamecock ends its 1790s life as a hardy democrat in name, it no longer has the sharp spurs and warning voice it once used to good effect. At the end of the decade, repressive measures and 'prudence' have made sure of that. The psychic, autobiographical challenge that the gamecock figure had posed in the first half of the 1790s had long since been worked through by the time Thelwall was driven west to Llyswen. Here, in May 1798, the renaming of the bird in honour of an 'honest, unshrinking down right Democrat' - Thelwall's description of Thomas Hardy in the letter-indicates the new, fully achieved, radical identity of the bird in its literary 'afterlife'. But that new identity is a dead end. Once a symbol of establishment tyranny, against which a vulpine Thelwall defined himself, and a spur to 
self-definition, opposition and action, it has now lost its fraught genetics. Moreover, the dangerous political satire of Thelwall's fables of the early 1790s cedes at the end of the 1798 letter to the anodyne allegory of mildly scurrilous social comedy and 'gossip', already bested by Gifford's scabrous anti-jacobin satire. And 'Thomas Hardy' the Welsh gamecock is, at the end, comically eclipsed by a hen - no longer the female victim of a barnyard tyrant, but like William Hazlitt (whom Thelwall in a letter of November 1803 would call 'disputatious' and 'metaphysical') wayward, individualistic, Pertelotian (hence 'Dame') - and very pretty. ${ }^{57}$

Department of English and Creative Writing Aberystwyth University

Notes

1. Michael Scrivener, 'John Thelwall and Popular Jacobin Allegory, 1793-95', ELH, 67, 3 (Winter 2000), 970, 968. See also Scrivener, Seditious Allegories: John Thelwall and Jacobin Writing (University Park, PA, 2001), 94, 112-18.

2. 'John Thelwall and Popular Jacobin Allegory', 956.

3. Politics for the People, or Hog's Wash, 8 (November 1793), 102.

4. Ibid., 102-3.

5. Ibid., 104-5.

6. Cecil Thelwall, The Life of John Thelwall (London, 1837), 108.

7. John Barrell, Imagining the King's Death: Figurative Treason, Fantasies of Regicide, 1793-1796 (Oxford, 2000), 106.

8. That Eaton 'dressed up' the original speech in 'very strong terms, which Thelwall would never have used', as claimed by Cecil Boyle Thelwall in her biography of her husband, has been rejected by most critics as being at odds with the evidence. See The Life of John Thelwall, 110; 'John Thelwall and Popular Jacobin Allegory', 970; and, expressing a different view, Mark Philp, The French Revolution and British Popular Politics (Cambridge, 1991), 71n.

9. Imagining the King's Death, 104.

10. The Trial of Daniel Isaac Eaton (London, 1794), 35-6.

11. Ibid., 40

12. Imagining the King's Death, 112.
13. 'John Thelwall and Popular Jacobin Allegory', 964.

14. Ibid., 956

15. Imagining the King's Death, 106.

16. 'John Thelwall and Popular Jacobin Allegory', 956, 959.

17. See http://www.familysearch.org/Eng/Search/ customsearchresults.asp? $L D S=2 \mathcal{E}$ last_name $=$ Vellam, accessed 15 April 2011. See also note 31, below.

18. John Thelwall, John Gilpin's Ghost; or, The Warning Voice of King Chanticleer: An Historical Ballad (London, 1795), iii-iv.

19. See Damian Walford Davies, Presences that Disturb: Models of Romantic Identity in the Literature and Culture of the 1790s (Cardiff, 2002), 289: 'A word about this same robbery which $\mathrm{Mr}$ Combs or some other persons committed upon the property I sent to you. I gave it as my opinion in my letter which appears to have been intercepted that [we?] ought to commence an action against the magistrates \& scoundrels concerned in both this robery [sic], \& the infamous \& illegal transaction of seizing your papers; \& I repeat to you again that if you have the spirit to do so, I will undertake to procure you an attorney to conduct the business, \& a Counsil to plead it without fee or reward. This is a piece of justice you owe to yourself, \& to the Country'.

20. See John Gilpin's Ghost, 2.

21. See Imagining the King's Death, 449.

22. See p. 4: 'It is a curious circumstance that not a soul in Oakham could ever get a single word of information from tradition or record - by hook or by crook, upon the important subject who the parents of this most special Attorney were, or whether he ever had either father or mother, till the fact was thus poetically revealed'.

23. 'John Thelwall and Popular Jacobin Allegory', 965.

24. Ibid., 966, 964.

25. The Gentleman's Magazine, 55 (May 1785), 341.

26. Thomas Paine, Rights of Man (London, 1791), $66,67$.

27. The Gentlemen's Magazine, 55 (May 1785), 341-2.

28. John Thelwall, The Peripatetic, ed. Judith Thompson (Detroit, 2001), 396.

29. Ibid., 211-12.

30. The Life of John Thelwall, 353-4.

31. My thanks to Tony Wellstead, Archives Assistant at the Record Office for Leicestershire, Leicester and Rutland. The bride's name is clearly recorded 
as 'Susannah Vellam', and this is confirmed by her own signature.

32. The image was taken by Simon Garbutt; I am grateful to him for allowing me to reproduce it here.

33. See Kenneth Varty, 'Reynard in Leicestershire and Rutland', Transactions of the Leicestershire Archaeological and Historical Society, 38 (1962-3), 2-4, and the same author's Reynard the Fox: A Study of the Fox in Medieval English Art (Leicester, 1967), 31-42 and 140. My thanks to David Trotter for these references. See also Jennifer Westwood and Jacqueline Simpson, The Lore of the Land: A Guide to England's Legends, from Spring-heeled Jack to the Witches of Warboys (London, 2005), 605.

34. See for example The Peripatetic, 158.

35. Ibid., 275.

36. See his commentary on the collection of classical busts at Wilton in the Monthly Magazine, 9 (February 1800), 16-19.

37. The Peripatetic, 36.

38. De Quincey offers the neologism in 'Suspiria de Profundis'; see Confessions of an English Opium-Eater and Other Writings, ed. Grevel Lindop (Oxford, 1998), 104.

39. 'John Thelwall and Popular Jacobin Allegory', 968

40. See for example The Peripatetic, 191.

41. See Richard Gravil, 'The Somerset Sound; or, The Darling Child of Speech', The Coleridge Bulletin, New Series 26 (Winter 2005), 12: 'first, "The Barking or Schoolboy Style", as in "And, the, Lord, said, un, to, Mo, ses" ... Second, the "Parish Clerk" style of delivery-allowing for syllables of different quantities and alternations of heavy and light, but without inflection of acute and grave (i.e. no ups and downs of pitch). Third, there is "The Clerical Drawl", served up in "portions of half-enunciated sound, uniformly divided in equal quantities ... terminating in imperfect murmurs" ... Fourth among Thelwall's heresies is "The Cathedral Chaunt", which he describes no further but [which] probably sounds something like Yeats'. The terms of Thelwall's classification are an interesting example of the continuities of his radical thought across that biographical fulcrum, the year 1800. As Gravil also records (p. 7n.) Thelwall claimed that he had noted the 'quantities and prosodial qualities of the syllables' of 'the entire service of the Church of England', should any clergyman wish to be coached in the craft.
Surely such instruction would have involved a fair amount of irony (but of what kind?) on Thelwall's part.

42. The Host addresses the nun's priest - 'Come neer, thou preest, com hyder, thou Sir John!' - and the narrator describes him as 'This sweete preest, this goodly man Sir John': 'Sir John' here being not a nickname for a priest (which it was) but apparently the priest's actual name.

43. Imagining the King's Death, 113.

44. See Presences that Disturb, 296.

45. The French Revolution and British Popular Politics, 75.

46. 'John Thelwall and Popular Jacobin Allegory', 969.

47. See Presences that Disturb, 306-7.

48. Image kindly supplied by the current proprietors of the Three Cocks Inn, Roy and Judith Duke.

49. Nicholas Roe, 'Coleridge and John Thelwall: The Road to Nether Stowey', in The Coleridge Connection, ed. Richard Gravil and Molly Lefebure (Basingstoke, 1990), 76.

50. See Judith Thompson, 'Citizen Juan Thelwall: In the Footsteps of a Free-Range Radical', Studies in Romanticism, 48, 1 (Spring 2009), 67-100.

'Free-range' resonates anew in the context of Thelwall-as-gamecock.

51. See David Simpson, 'Public Virtues, Private Vices: Reading Between the Lines of Wordsworth's "Anecdote for Fathers"', in Subject to History: Ideology, Class, Gender, ed. David Simpson (Ithaca, NY, 1991), 163-90.

52. S. T. Coleridge, Lectures 1795 on Politics and Religion, ed. Lewis Patton and Peter Mann (Princeton, NJ, 1971), 8. See also p. 37.

53. The Jerwood Centre, Dove Cottage, 2010.58. Quoted by kind permission of The Wordsworth Trust. My thanks to the Curator, Jeff Cowton.

54. See Michael Scrivener, 'The Rhetoric and Context of John Thelwall's "Memoir"', in Spirits of Fire: English Romantic Writers and Contemporary Historical Methods, ed. G. A. Rosso and Daniel P. Watkins (Rutherford, NJ, 1990), 112-30.

55. See John Thelwall, Poems, Chiefly Written in Retirement (Hereford, 1801), xxxvi-xxxvii. In the postscript to the letter to Hardy, Thelwall states that he was assaulted by one of his Llyswen neighbours, and was 'under the necessity of indicting' the assailant - 'a fellow of a very desperate Character' - 'at the last quarter sessions at Brecknock'. This is true; see Presences that Disturb, 281 n.43. 
56. 'Mary \& Sophia Goddard, \& their mother Mrs Goddard': the Goddards lived in Norwich, where Thelwall knew them from the mid-1790s. The Thelwall manuscript ('The Derby MS') recently discovered by Judith Thompson contains 'An Occasional Address. Spoken by the late Miss Goddard, at the Theatre Royal Norwich'; Yasmin Solomonescu informs me that this particular Miss Goddard was 'an actress who had been a "constant attendant" of Thelwall's political lectures in the mid-1790s' and that Thelwall wrote the 'Address' for her as an expression of her gratitude 'to her teachers at the Norwich Theatre Royal, where she made her stage debut'. Solomonescu believes there is 'a small possibility' that the mother, Mrs Goddard, is the 'Mrs G_-' to whom Thelwall refers as "one of the new "flock" of women who attended his elocutionary lectures in the early $1800 s^{\prime}$. 'Three white sisters ... named Sara, Ester,
\& Rose': Sarah (born 1780), Esther (b. 1781) and Rosa White (b. 1782), daughters of William White and his wife Rose Hannah, who lived in Norwich. In the November 1796 issue of the Monthly Magazine (p. 808), Thelwall published a poem to Rosa White - 'Stanzas to Rosa Bella Bianca, on her Birth-day', dated 'Aug 8, $1796^{\prime}$ - which Coleridge praised in a letter of 17 December 1796 (Collected Letters of Samuel Taylor Coleridge, ed. E. L. Griggs, 6 vols (Oxford, 1956-71), I, 279), and which was collected in Thelwall's Poems, Chiefly Written in Retirement in 1801. I am very grateful to Judith Thompson and Yasmin Solomonescu for identifying these sisters.

57. Presences that Disturb, 318. It is possible that Thelwall is referring here to Hazlitt's older brother, John, the painter and miniaturist, though this is unlikely. 